\title{
Influence of Codoping on the Optical Properties of ZnO Thin Films Synthesized on Glass Substrate by Chemical Bath Deposition Method
}

\author{
G. Shanmuganathan and I. B. Shameem Banu \\ Department of Physics, B.S.Abdur Rahman University, Chennai 600048, India \\ Correspondence should be addressed to G. Shanmuganathan; shan25@bsauniv.ac.in
}

Received 18 June 2014; Accepted 5 August 2014; Published 31 August 2014

Academic Editor: Weida Hu

Copyright (C) 2014 G. Shanmuganathan and I. B. S. Banu. This is an open access article distributed under the Creative Commons Attribution License, which permits unrestricted use, distribution, and reproduction in any medium, provided the original work is properly cited.

\begin{abstract}
Fe and $\mathrm{K}$ simultaneously doped $\mathrm{ZnO}$ thin films $\mathrm{Zn}_{0.99} \mathrm{~K}_{0.01}(\mathrm{Fe})_{x} \mathrm{O}(x=1,2,3$, and 4\%) were synthesized by chemical bath deposition method. The XRD investigation reveals that all the doped $\mathrm{ZnO}$ thin films are in hexagonal wurtzite crystal structure without impurity phases. With increase in Fe concentration, the growth of thin films along $c$ axis is evident from the XRD which indicates the increase in intensity along (002) direction. The same is visible from the surface morphology which shows the formation of hexagonal structure for higher Fe concentration. The topography shows gradual variation with Fe incorporation. The optical energy band gap obtained from the transmittance spectrum decreases from 3.42 to $3.06 \mathrm{eV}$ with increase in Fe concentration indicating the red shift and this trend is consistent with the earlier experimental results. The UV emission is centered around $3.59 \mathrm{eV}$. The optical constants such as refractive index, extinction coefficient, and absorption coefficient which are essential for the optoelectronic applications were also determined.
\end{abstract}

\section{Introduction}

Zinc oxide is an amazing material for numerous applications such as photodetectors, antireflecting coating, thin film solar cell, LEDs, and lithium-ion batteries [1-5] due to its wide band gap $(3.445 \mathrm{eV})$ and high binding energy $(60 \mathrm{eV})[1$, 6]. Due to its unique optical, semiconductor, and optical properties, $\mathrm{ZnO}$ thin films have been extensively studied for various applications. Several methods such as chemical bath deposition, MOCVD, melt growth, ion implementation, DC reactive magnetron cosputtering, and hydrothermal and simple chemical pyrolysis have been used to synthesize $\mathrm{ZnO}$ thin films [7-13]. Of late, $\mathrm{ZnO}$ thin films are being fabricated by codoping for enhancing the efficiency of $\mathrm{ZnO}$ film in optoelectronic devices.

Alkali elements are well-known materials for tuning $\mathrm{ZnO}$ optical and electrical behaviors. Alkali doped $\mathrm{ZnO}$ films have been broadly investigated in recent decades. Kim et al. reported that, when $\mathrm{K}$ doped $\mathrm{ZnO}$ thin films were synthesized on $\mathrm{Al}_{2} \mathrm{O}_{3}$ (001), the optical properties were improved [14].
$\mathrm{Xu}$ et al. also reported that the optical emission was emerged while $\mathrm{K}$ doped $\mathrm{ZnO}$ was annealed during different temperatures [15]. Depending on the different types of substrates such as $\mathrm{Si}$ (111), $\mathrm{ZnO}$ exhibited different emissions such as green and yellow emissions at $529-567 \mathrm{~nm}$ and $600-640 \mathrm{~nm}$ due to oxygen vacancy and oxygen interstitials, respectively [16]. For Na-doped $\mathrm{ZnO}$, the carrier mobility was $2.1 \mathrm{~cm}^{2} \mathrm{~V}^{-1} \mathrm{~S}^{-1}$ and structural and optical properties were reported elsewhere $[17,18]$. Li doped $\mathrm{ZnO}$ is also used for developing the ferroelectric, optical, and multiphonon properties of $\mathrm{ZnO}$ semiconductor $[19,20]$. In latest decades, Fe doped $\mathrm{ZnO}$ has been synthesized for optical properties [21] because Fe is well-known optical emitter in doped $\mathrm{ZnO}$. Zhang et al. reported [22] that the optical mechanism of $\mathrm{ZnO}$ alloyed with Fe ion. Not only optical properties but also Fe is well known as a doping element for altering the magnetic and electrical properties [23-25]. The extensive literature survey shows that only few works were reported on the optical properties of dual doped $\mathrm{ZnO}$ films. Some experimental works such as $\mathrm{Al}-$ $\mathrm{K}$ [26], Li-N [27], Li-Mg [28], Fe-Co [29], and Fe-N [30] 
reported the dual doped $\mathrm{ZnO}$ to investigate the optical and magnetic properties. However, the combination of alkali and transition metals (TM) dual doped $\mathrm{ZnO}$ is rarely reported.

As per the literature till date the study on the optical properties of $\mathrm{K}$ and $\mathrm{Fe}$ doped $\mathrm{ZnO}$ thin films has not been reported yet. Both $\mathrm{Fe}$ and $\mathrm{K}$ when doped to $\mathrm{ZnO}$ separately, they modify the band gap and also the luminescence characteristics and hence, the $\mathrm{Fe}$ and $\mathrm{K}$ simultaneously doped to $\mathrm{ZnO}$ can bring out some interesting results and so in the present study, $(\mathrm{K}, \mathrm{Fe})$ codoped $\mathrm{ZnO}$ thin films were investigated for the influence on the optical properties. The optical properties of $\mathrm{K}$ doped $\mathrm{ZnO}$ films show that $1 \%$ of $\mathrm{K}$ exhibited better optical properties [31]. For further optical investigation, the transition metal $\mathrm{Fe}$ is added into $\mathrm{ZnO}: \mathrm{K}(1 \%)$ due to its excellent optical emission property. The simple chemical bath deposition method is employed to fabricate these films. The influence of Fe concentration on the optical behavior has been revealed in the transmittance and photoluminescence sections. In the present work, $1 \% \mathrm{~K}$ doped $\mathrm{ZnO}$ would be indicated as $\mathrm{ZnO}: \mathrm{K}(1 \%)$. The main purpose of this study is to examine the effect of Fe ion concentration on optical properties of $\mathrm{ZnO}: \mathrm{K}(1 \%)$ films.

\section{Experimental Work}

Codoped (K, Fe) $\mathrm{ZnO}$ films were synthesized by chemical bath deposition method. Here, $\mathrm{ZnCl}_{2}$ (AR MERCK), $\mathrm{KOH}$ (AR MERCK), $\mathrm{KCH}_{3} \mathrm{COO}$ (AR MERCK), and $\mathrm{FeSO}_{4} \cdot 7 \mathrm{H}_{2} \mathrm{O}$ (AR MERCK) were the precursor materials and doping source materials, respectively. Initially, $\mathrm{ZnCl}_{2}$ and $\mathrm{KOH}$ were dissolved in the triple distilled water with $1: 1$ ratio and stirred using magnetic stirrer at $60^{\circ} \mathrm{C}$ for 10 minutes. Then one percentage of potassium acetate was added in $1: 1$ ratio prepared homogeneous solution. After that, different percentages of $\mathrm{Fe}(1$ at $\%, 2$ at $\%, 3$ at \%, and 4 at $\%)$ were added to the solution for doping. In the synthesized homogenous solution, $\mathrm{HCl}$ is added to keep the $\mathrm{pH}$ at 8 . The solution was cooled to room temperature and microglass slide was used as substrate. The substrate was cleaned by $\mathrm{HCl}$, acetone, and double distilled water. Then the cleaned substrate was immersed vertically in the solution using substrate holder. Finally, the solution was steadily stirred by magnetic stirrer to get the uniformly coating on the substrate. After 45 minutes of deposition, the uniform coated substrates were taken out from the solutions and cleaned with double distilled water and then dried in air. Finally, thin films are kept in the furnace and calcined at $400^{\circ} \mathrm{C}$ for 1 hour.

\section{Results and Discussion}

3.1. Structural Analysis. The XRD pattern of codoped (K, Fe) $\mathrm{ZnO}$ thin films is shown in Figure 1. All the thin films exhibit hexagonal crystal phase and it is confirmed with standard JCPDS card (PDF numbers 891397 and 890510) number. In XRD pattern, the three prominent peaks such as (100), (002), and (101) were obtained for all films without any secondary phase. In our previous report, three prominent peaks such as (100), (002), and (101) were observed for $\mathrm{ZnO}: \mathrm{K}(1 \%)$

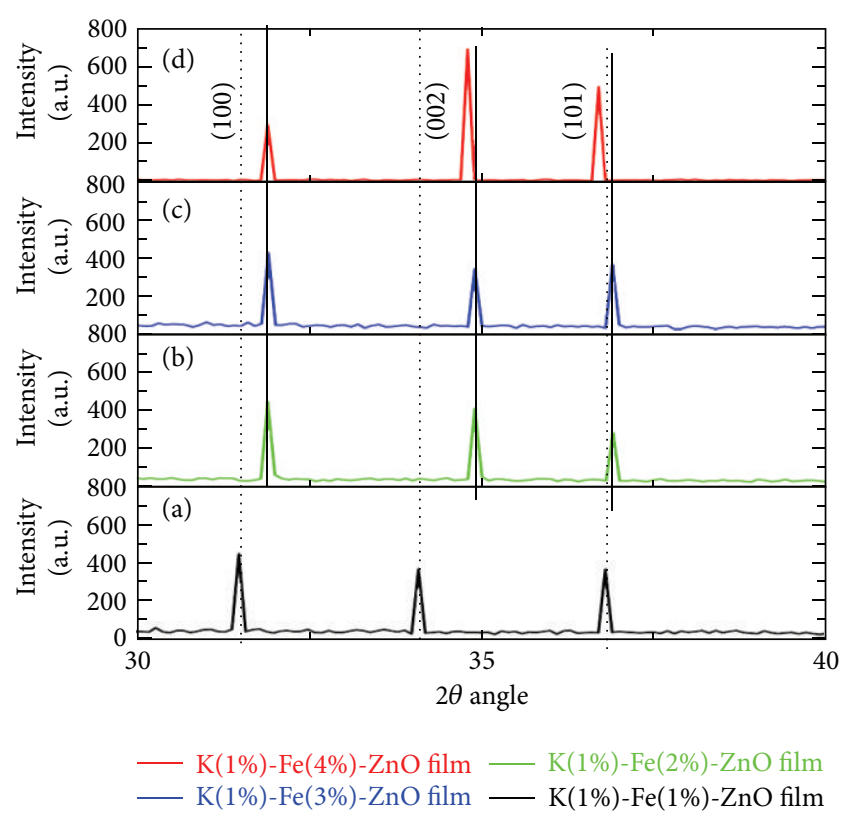

FIgUre 1: XRD pattern of (K (1\%), Fe) codoped $\mathrm{ZnO}$ for $\mathrm{Fe}$ concentrations: (a) $1 \%$, (b) $2 \%$, (c) $3 \%$, and (d) $4 \%$.

thin film [31]. In the present work, when Fe concentration is increased, the crystal properties of the codoped $\mathrm{ZnO}$ thin films have changed. The low intensity peak was observed for $\mathrm{ZnO}: \mathrm{K}(1 \%)$ [31]. However, in the present work, it is observed that when $\mathrm{Fe}$ is introduced, the intensity of three prominent peaks has changed. The variation in intensity indicates the incorporation of $\mathrm{Fe}$ ions in the lattice of $\mathrm{ZnO}$ site. In the doping process, the three prominent peaks are shifted from higher to lower angles due to the different ionic radius of Fe such as $\mathrm{Fe}^{3+}$ and $\mathrm{Fe}^{2+}$. For 2, 3, and 4\% of Fe, the three prominent peaks shifted to higher angle than $1 \% \mathrm{Fe}$ due to the inclusion of $\mathrm{Fe}^{3+}(0.068 \mathrm{~nm})[11,32]$. For $4 \% \mathrm{Fe}$, the $(002)$ peak shifts to lower angle due to the high ionic radius $(0.078)$ of $\mathrm{Fe}^{2+}[33,34]$. In the entire XRD pattern, the intensity of (002) plane varied for different Fe ion concentrations which indicates that the film is grown along $c$-axis. In the XRD pattern, the high intensity of (002) plane reveals the improved crystallinity [35]. The full width at half maximum of (002) peaks is significantly varied with various $\mathrm{Fe}$ concentrations. For $4 \%$ Fe, the FWHM is lower than others. Saha et al. reported that the low FWHM reveals the deterioration of the crystallinity [36]. For the codoped $\mathrm{ZnO}$ film, average crystal size and average crystal strain were calculated and are summarized in Table 1.

The crystalline sizes of thin films are calculated using Scherrer formula:

$$
D=\frac{0.9 \lambda}{\beta \cos \theta}
$$

3.2. Surface Morphology Analysis and EDAX Spectrum. Figure 2 shows the surface morphology of (K, Fe) codoped $\mathrm{ZnO}$ films investigated by field emission scanning electron 


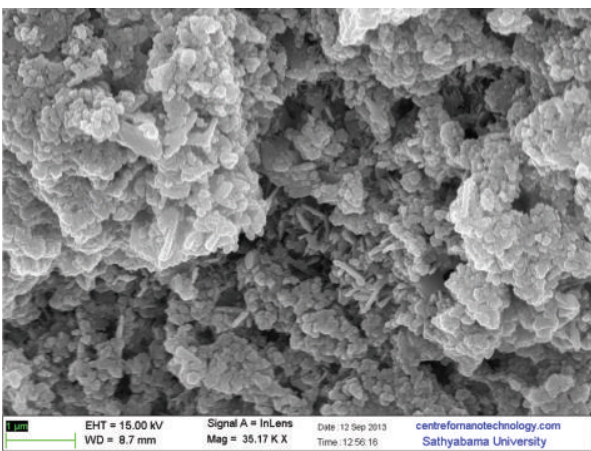

(a)

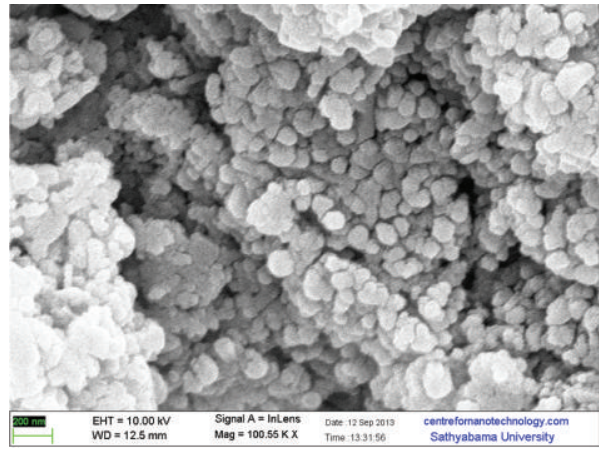

(c)

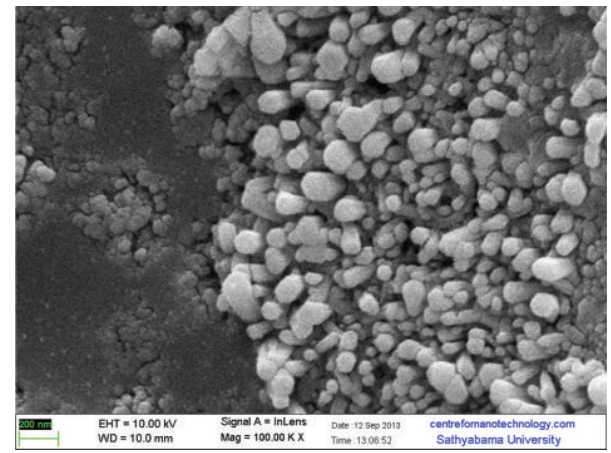

(b)

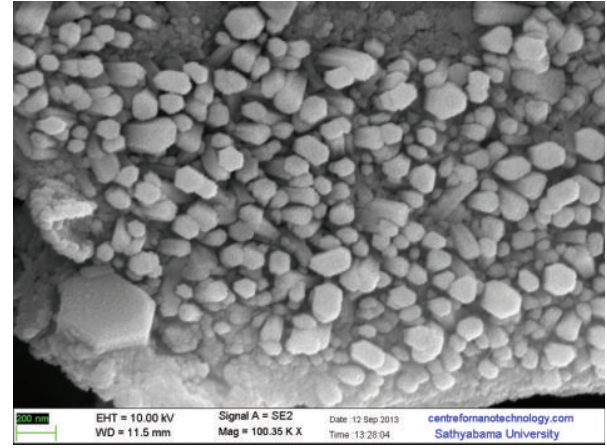

(d)

Figure 2: Surface morphology (FESEM) of (K (1\%), Fe) codoped ZnO for Fe concentrations: (a) 1\%, (b) 2\%, (c) 3\%, and (d) $4 \%$.

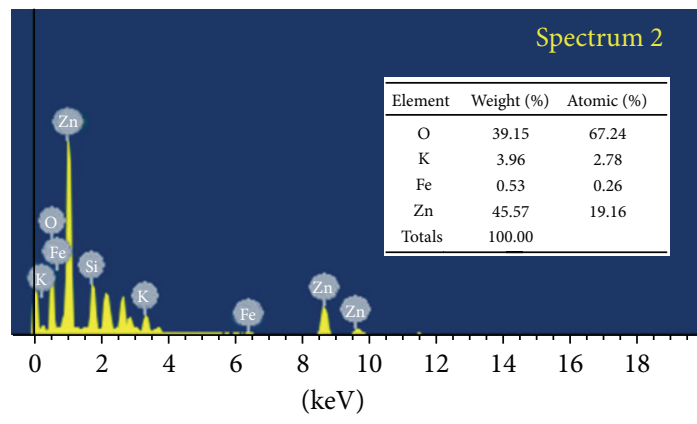

Full scale 32709 cts cursor: 0.000

(a)

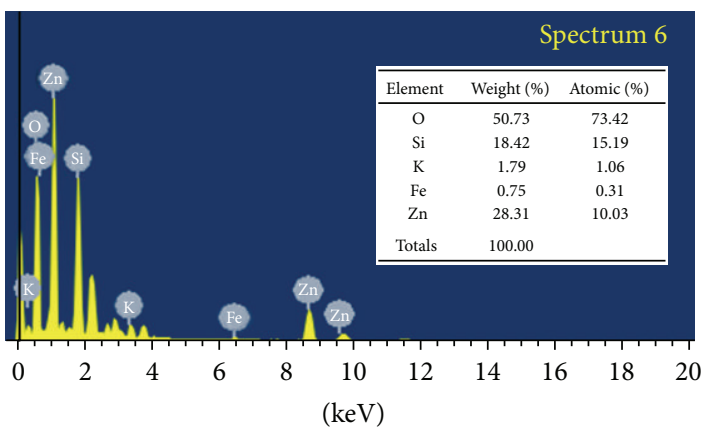

Full scale 18948 cts cursor: 0.000

(c)

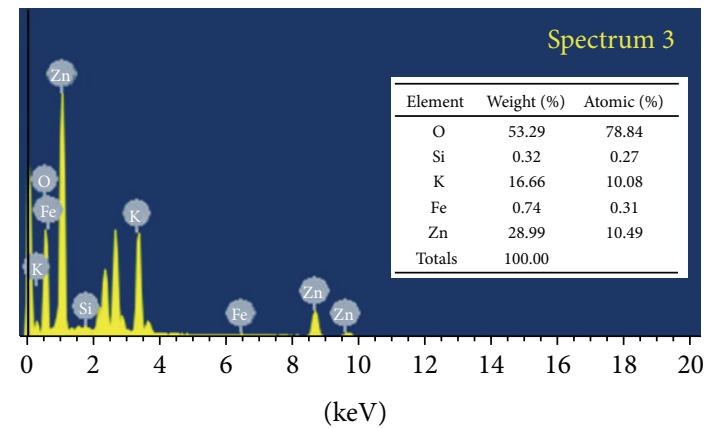

Full scale 12293 cts cursor: 0.000

(b)

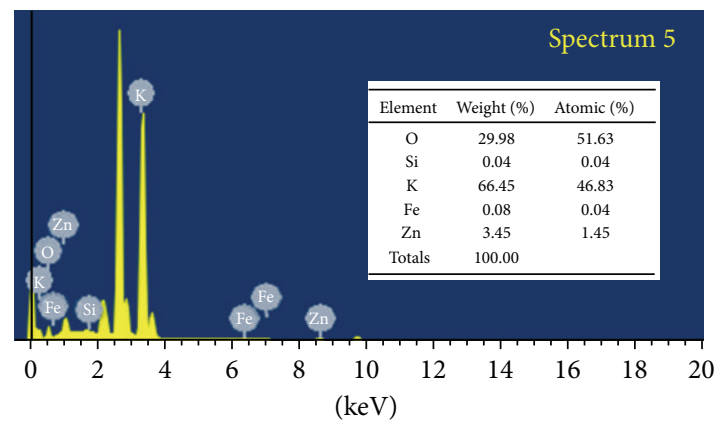

Full scale 36002 cts cursor: 0.000

(d)

Figure 3: EDAX spectrum of (K (1\%), Fe) codoped ZnO for Fe concentrations: (a) 1\%, (b) 2\%, (c) 3\%, and (d) 4\%. 


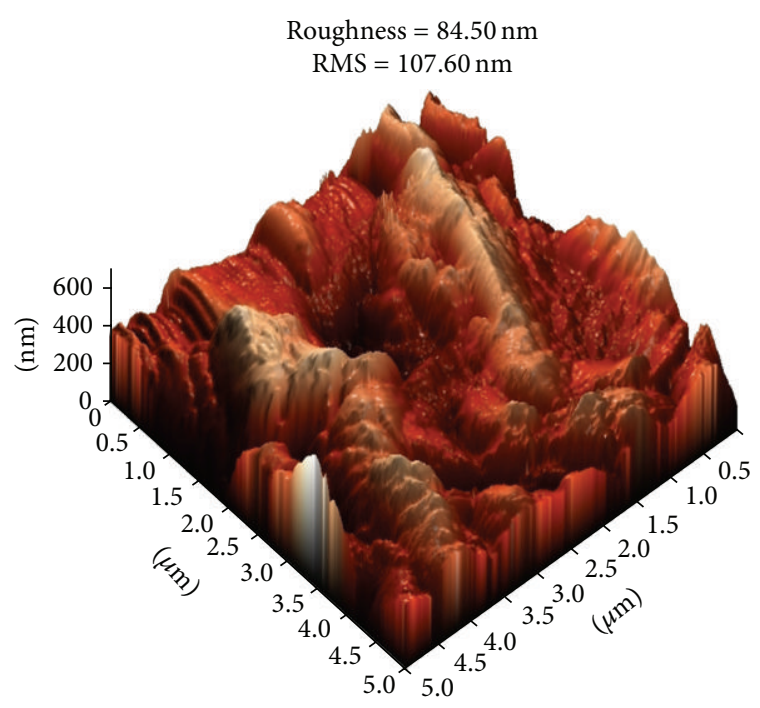

(a)

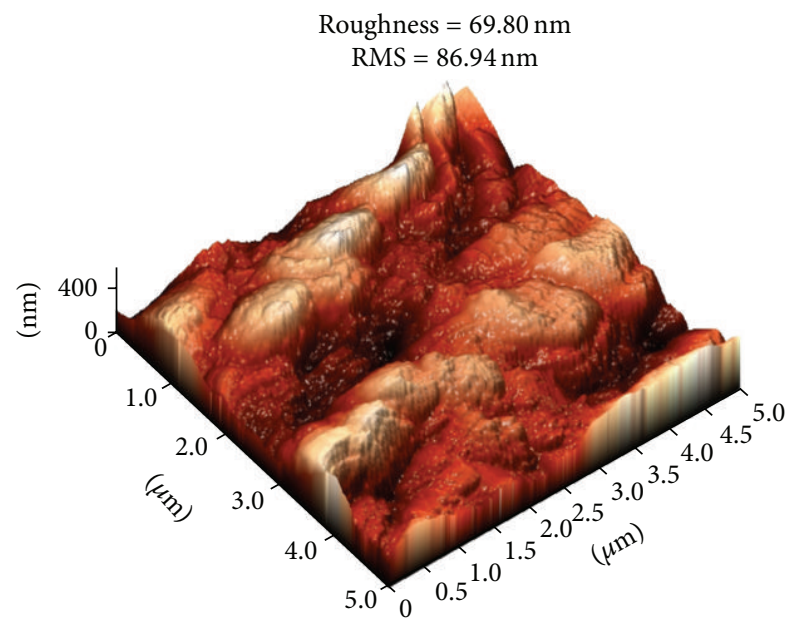

(c)

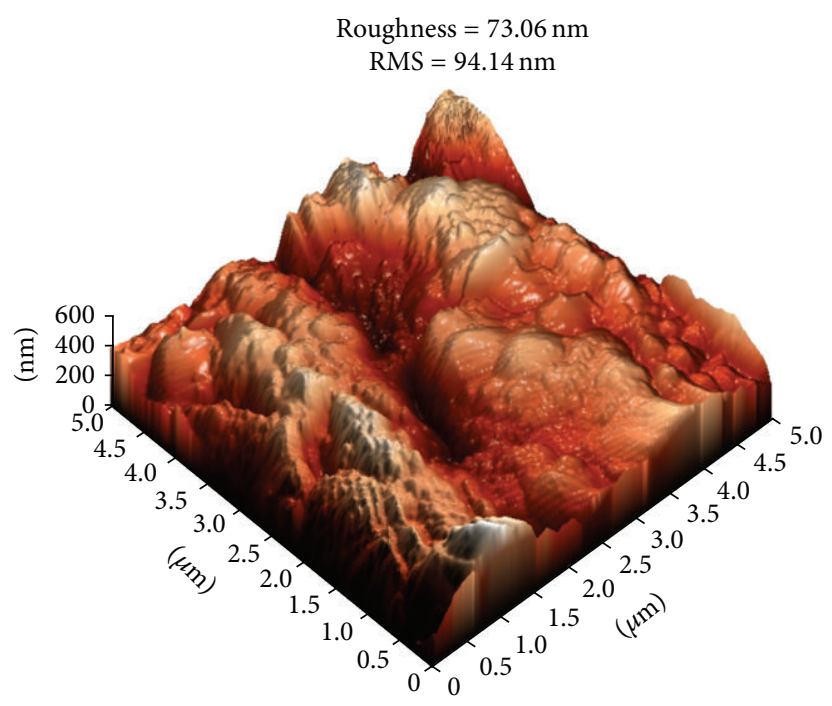

(b)

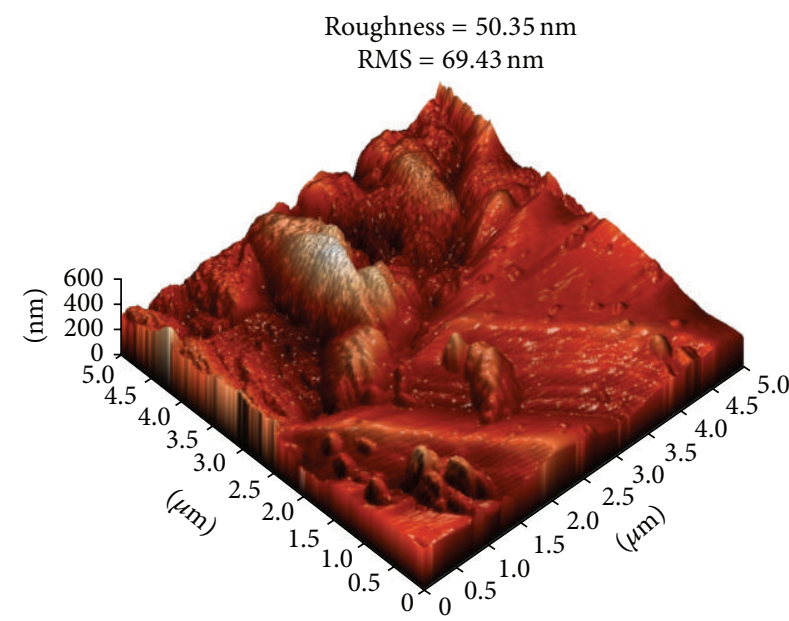

(d)

Figure 4: Atomic force microscope of (K (1\%), Fe) codoped ZnO for Fe concentrations: (a) 1\%, (b) 2\%, (c) 3\%, and (d) 4\%.

microscope (SUPRA “55”). SEM image shows that morphology changes with Fe doping concentrations. The film exhibits small grains of varied size at different level of Fe. The element compositions such as $\mathrm{Zn}, \mathrm{O}, \mathrm{K}$, and Fe were confirmed by energy dispersive analysis X-ray spectroscopy and are shown in Figure 3. In all EDAX spectrums, the substrate peak is presented between 2.4 and $2.5 \mathrm{eV}$ [31].

3.3. Surface Topology. In Figure 4 three-dimensional (3D) surface topography of $(\mathrm{K}, \mathrm{Fe})$ codoped $\mathrm{ZnO}$ thin films is presented. Surface topography was scanned at $5 \times 5 \mu \mathrm{m}$ in tapping mode. The average roughness and root mean square values were determined. The average roughness is $84.50 \mathrm{~nm}$, $73.06 \mathrm{~nm}, 69.80 \mathrm{~nm}$, and $50.35 \mathrm{~nm}$ at level 1, 2, 3, and $4 \%$ Fe, respectively. The RMS values are $107.60 \mathrm{~nm}, 94.14 \mathrm{~nm}$, $86.94 \mathrm{~nm}$, and $69.43 \mathrm{~nm}$ for 1, 2, 3, and 4 at \% Fe, respectively. The decreases in average roughness and RMS show that the crystalline quality of the codoped $\mathrm{ZnO}$ thin films has been improved by increase in Fe concentration. The low roughness indicates the enhancement of crystalline quality [37].

3.4. Transmittance Spectrum and Optical Band Gap. The transmittance spectrum of $(\mathrm{K}, \mathrm{Fe})$ codoped $\mathrm{ZnO}$ nanofilms is shown in Figure 5. The $(\mathrm{K}, \mathrm{Fe})$ codoped $\mathrm{ZnO}$ thin films exhibit a low transmittance as seen in Figure 5. In the visible region, the transmittance is $50 \%, 45 \%, 25 \%$, and $10 \%$ for 1 , 2,3 , and 4 at $\% \mathrm{Fe}$, respectively, and the transmittance is found to decrease with increase in Fe dopant concentration. The film thickness is one of the main factors for low transmittance. In the doping process, the film thickness is $4.348 \mu \mathrm{m}, 4.690 \mu \mathrm{m}, 5.078 \mu \mathrm{m}$, and $6.520 \mu \mathrm{m}$ for $1,2,3$, and $4 \% \mathrm{Fe}$, respectively. $\mathrm{Xu}$ et al. have reported that the optical transmittance obviously reduced in the visible region due to the Fe ion concentrations $[38,39]$. Prajapati et al. have studied that the low transmittance was obtained for Fe doped $\mathrm{ZnO}$ thin films due to lattice defects into $\mathrm{ZnO}$ lattice [40]. 
TABLE 1: The peak position, FWHM, average crystalline size, lattice constant, and average lattice strain for the (K, Fe) codoped $\mathrm{ZnO}$ thin films.

\begin{tabular}{|c|c|c|c|c|c|c|c|c|c|c|}
\hline \multirow{2}{*}{ Materials } & \multicolumn{3}{|c|}{ Peak positions } & \multicolumn{3}{|c|}{ FWHM of peaks } & \multirow{2}{*}{$\begin{array}{l}\text { Average crystalline } \\
\text { size }(\mathrm{nm})\end{array}$} & \multicolumn{2}{|c|}{ Lattice constant (nm) } & \multirow{2}{*}{$\begin{array}{l}\text { Average crystalline } \\
\text { strain (nm) }\end{array}$} \\
\hline & $(100)$ & $(002)$ & $(001)$ & $(100)$ & $(002)$ & $(101)$ & & $a$ & $b$ & \\
\hline $\begin{array}{l}\mathrm{K}(1 \%)-\mathrm{Fe}(1 \%)-\mathrm{ZnO} \\
\text { film }\end{array}$ & 31.49 & 34.10 & 36.80 & 0.1088 & 0.1060 & 0.1076 & 77.39 & 0.3043 & 0.5270 & 0.0879 \\
\hline $\begin{array}{l}\mathrm{K}(1 \%)-\mathrm{Fe} \\
(2 \%)-\mathrm{ZnO} \text { film }\end{array}$ & 31.90 & 34.90 & 36.90 & 0.1105 & 0.1095 & 0.1081 & 76.47 & 0.2862 & 0.4957 & 0.0882 \\
\hline $\begin{array}{l}\mathrm{K}(1 \%)-\mathrm{Fe} \\
(3 \%)-\mathrm{ZnO} \text { film }\end{array}$ & 31.90 & 34.90 & 36.90 & 0.1102 & 0.1093 & 0.1088 & 76.08 & 0.3004 & 0.5203 & 0.0882 \\
\hline $\begin{array}{l}\mathrm{K}(1 \%)-\mathrm{Fe} \\
(4 \%)-\mathrm{ZnO} \text { film }\end{array}$ & 31.90 & 34.80 & 36.70 & 0.1014 & 0.1009 & 0.1002 & 82.55 & 0.3012 & 0.5217 & 0.0815 \\
\hline
\end{tabular}

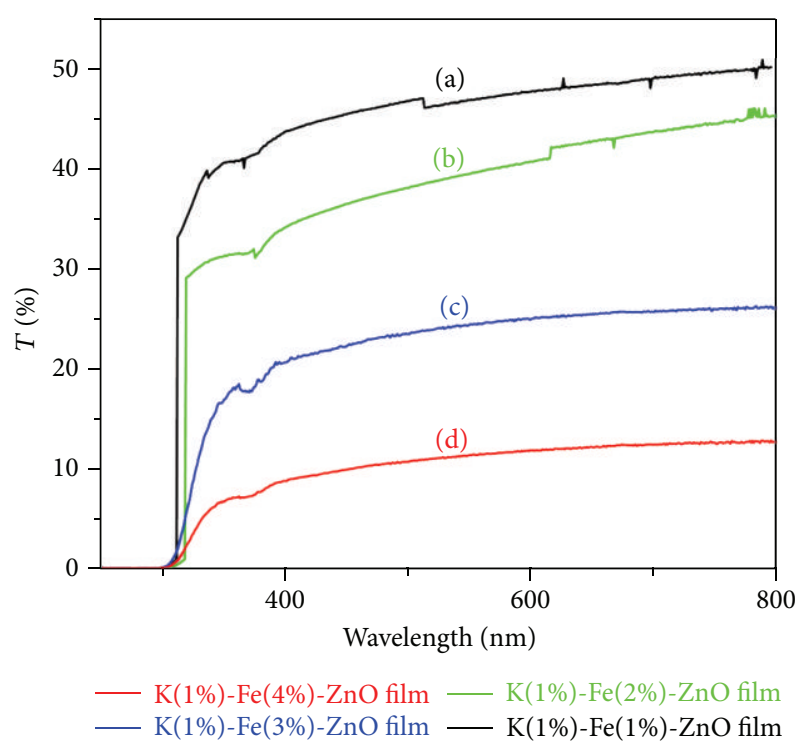

FIGURE 5: UV transmittance of (K (1\%), Fe) codoped $\mathrm{ZnO}$ for $\mathrm{Fe}$ concentrations: (a) $1 \%$, (b) $2 \%$, (c) $3 \%$, and (d) $4 \%$.

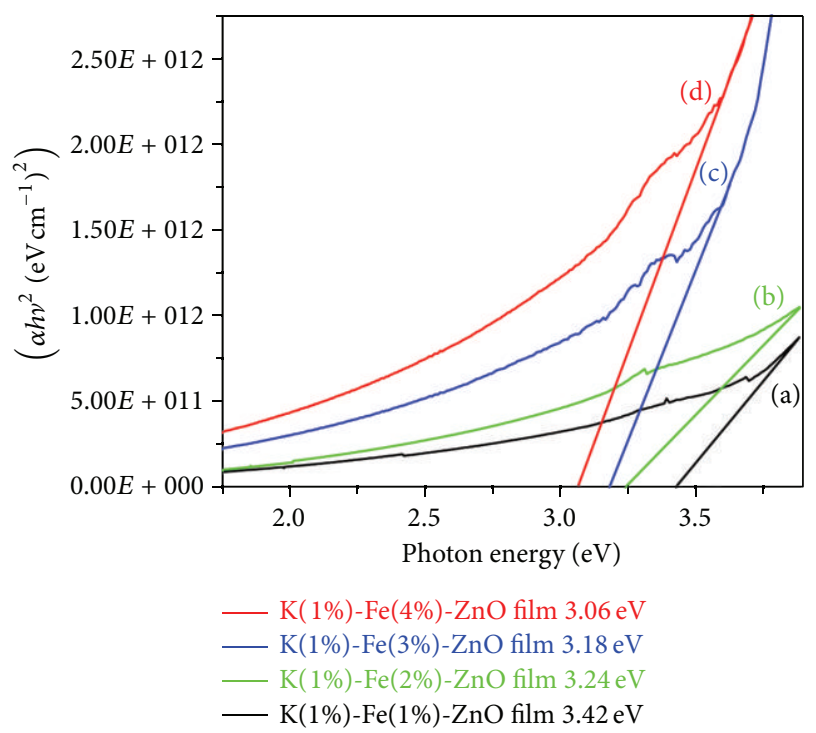

Figure 6: Optical band gap of (K (1\%), Fe) codoped $\mathrm{ZnO}$ for $\mathrm{Fe}$ concentrations: (a) $1 \%$, (b) $2 \%$, (c) $3 \%$, and (d) $4 \%$.
Due to the film thickness, the incident light is much absorbed and so the transmittance light intensity is less pronounced. This fact is well reported by the absorption coefficient values of these thin films (Figure 9).

The optical band gap of codoped (K, Fe) nano- $\mathrm{ZnO}$ films is calculated from the following formula:

$$
\begin{gathered}
\alpha=\frac{1}{d} \ln \left(\frac{1}{T}\right), \\
(\alpha h \nu)^{2}=A\left(h v-E_{g}\right),
\end{gathered}
$$

where $h \nu$ is photon energy and $E_{g}$ is energy gap. The optical band gaps of codoped $\mathrm{ZnO}$ films are shown in Figure 6. The optical energy gap can be obtained by extrapolating the linear part to $x$-axis. In our previous work, the band gap was $3.94 \mathrm{eV}$ for $\mathrm{ZnO}: \mathrm{K}(1 \%)$ film [31]. The energy gap reduces due to the increase in Fe doping concentration. The band gap values are $3.42 \mathrm{eV}, 3.24 \mathrm{eV}, 3.18 \mathrm{eV}$, and $3.06 \mathrm{eV}$ for $1,2,3$, and 4 at $\% \mathrm{Fe}$, respectively, thus indicating the red shift. C. S. Prajapati et al. reported that when $\mathrm{Fe}$ ion was doped with $\mathrm{ZnO}$, the optical band gap changes [40]. However, $\mathrm{Xu}$ and Li reported that the band gap of $\mathrm{ZnO}$ was increased by Fe ion concentrations [38]. The red shift was also observed for $\mathrm{ZnO}$ thin films due to the high doping material, renormalization effect [41], and film thickness [21, 42]. Among the three factors, the change in the optical band gap also depends on the thickness of the thin film.

3.5. Optical Constants. The refractive index of codoped $\mathrm{ZnO}$ films is calculated from the following formula:

$$
\begin{gathered}
n=\left(\frac{1+R}{1-R}\right)+\sqrt{ }\left(\frac{4 R}{(1-R)^{2}}\right)-k^{2}, \\
k=\frac{\alpha \lambda}{4 \pi} .
\end{gathered}
$$

The refractive index of codoped $\mathrm{ZnO}$ thin films as function of wavelength is shown in Figure 7. The refractive index varies with variation in Fe concentrations. In the visible region the light is normally dispersed due to the contribution of virtual electronic transition [43] and lower dense medium. For the $375 \mathrm{~nm}$, the refractive index of codoped $\mathrm{ZnO}$ thin film is 5.3, $3.2,4.3$, and 6.2 for $1,2,3$, and $4 \% \mathrm{Fe}$, respectively. The thin 


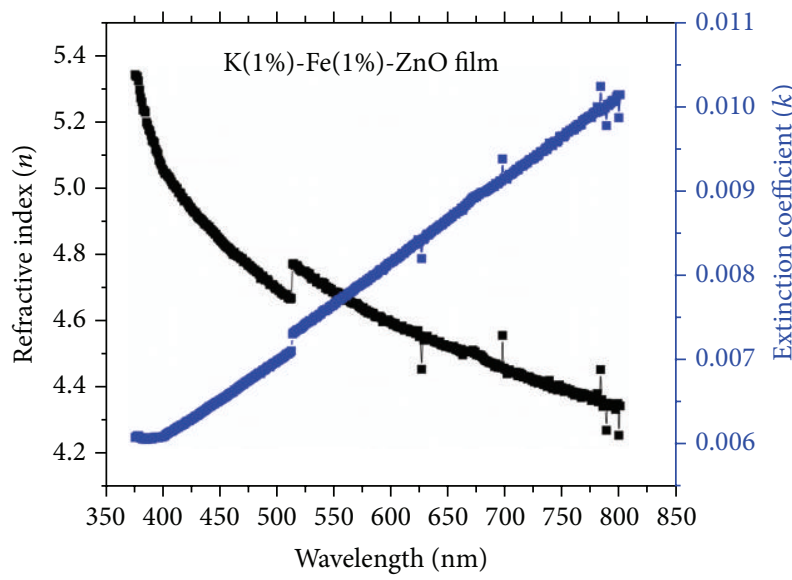

(a)

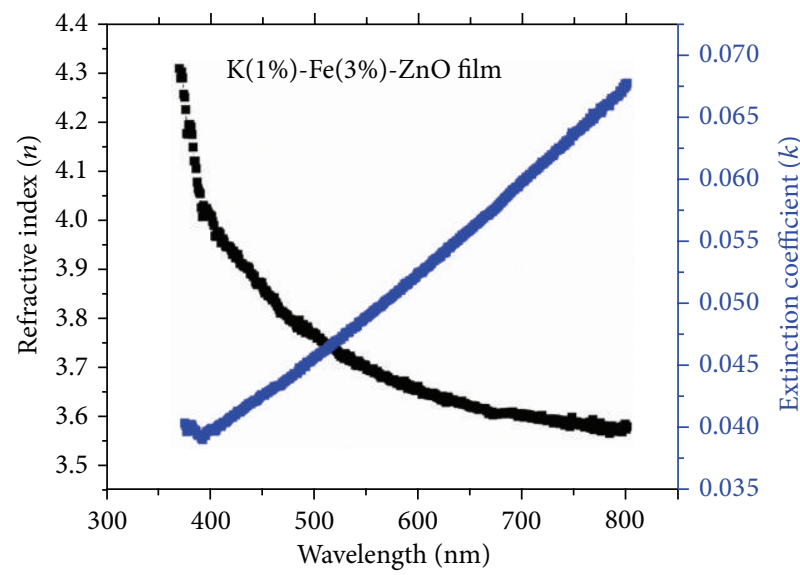

(c)

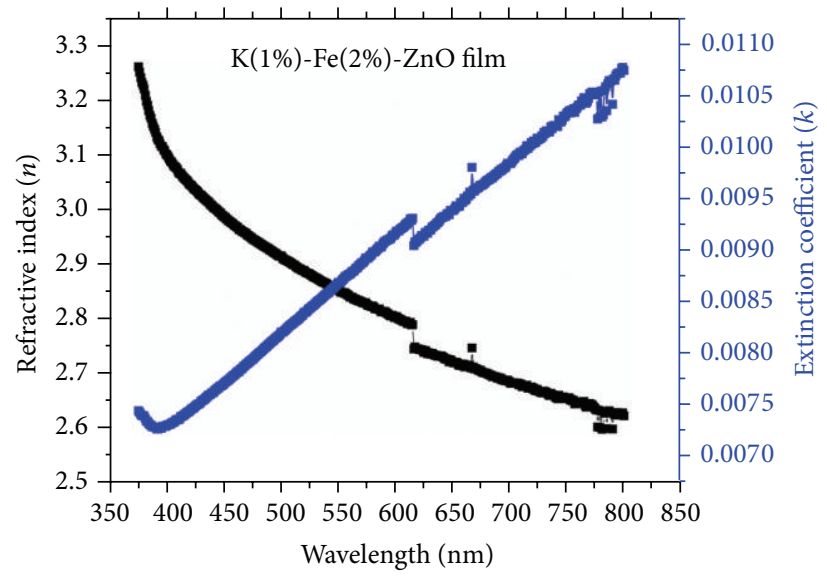

(b)

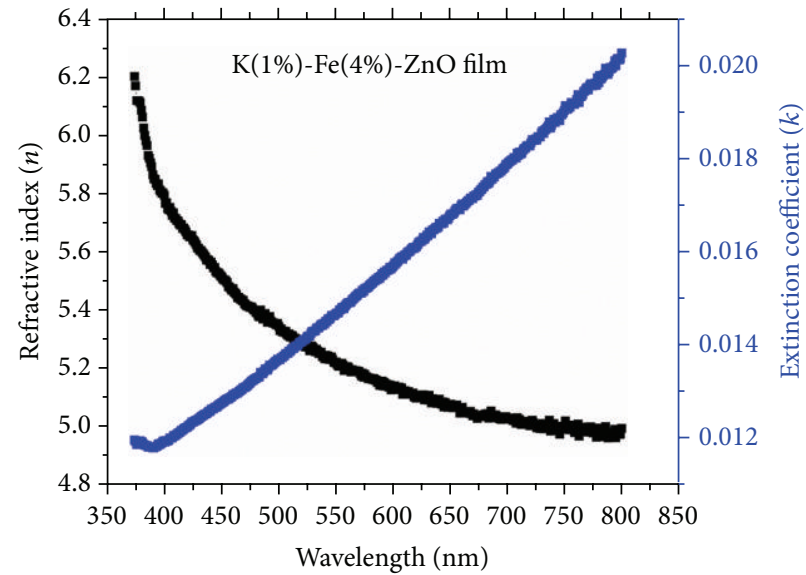

(d)

Figure 7: Refractive index of (K (1\%), Fe) codoped ZnO for Fe concentrations: (a) 1\%, (b) 2\%, (c) 3\%, and (d) 4\%.

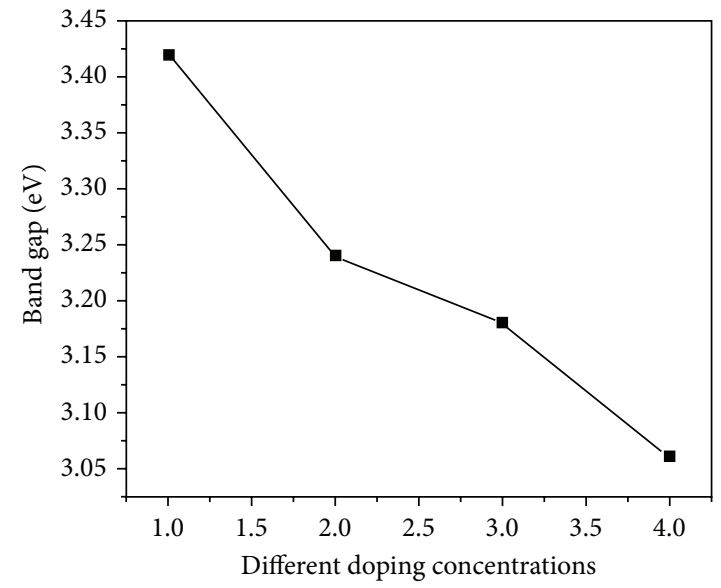

(a)

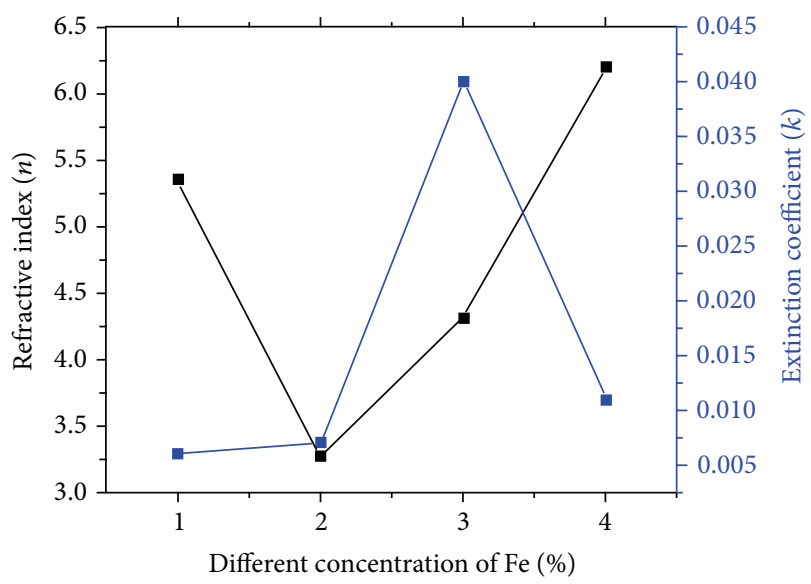

(b)

Figure 8: The figure shows (a) band gap versus different Fe \% and (b) refractive index and extinction coefficient versus different Fe \%. 


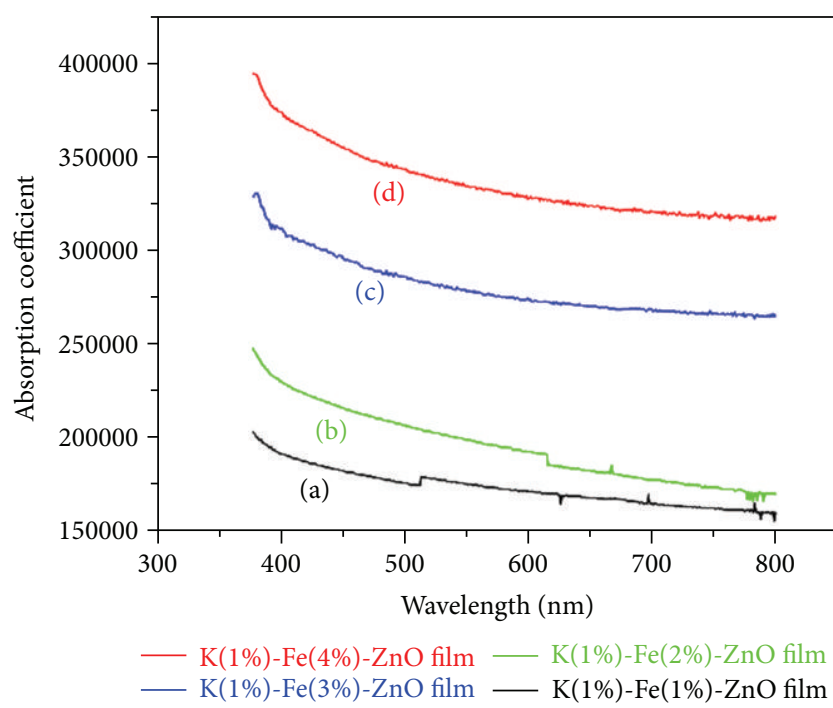

FIGURE 9: Absorption coefficient of (K (1\%), Fe) codoped $\mathrm{ZnO}$ for Fe concentrations: (a) $1 \%$, (b) $2 \%$, (c) $3 \%$, and (d) $4 \%$.

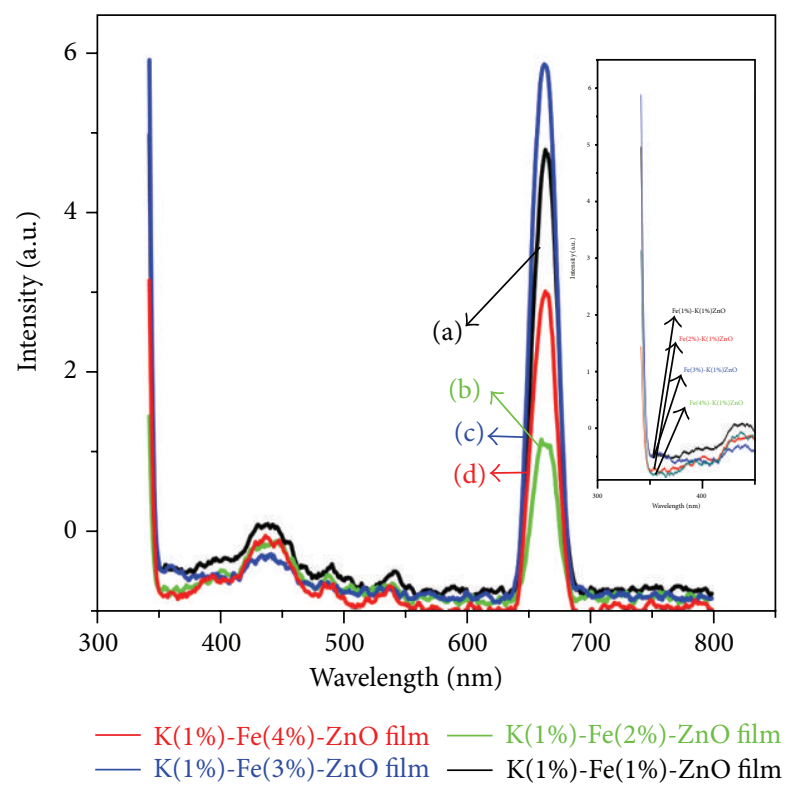

FIgURE 10: Photoluminescence spectrum of (K (1\%), Fe) codoped $\mathrm{ZnO}$ for Fe concentrations: (a) 1\%, (b) 2\%, (c) 3\%, and (d) $4 \%$.

films exhibit significant changes and are also suitable for integrated optical device application. The normal dispersion indicates that the films do not have voids or any defects. The lower values of extinction coefficient indicate the smoothness of the thin film.

Figure 8 shows the variation of optical band gap, refractive index, and extinction coefficient of Fe concentrations. In Figure $8(\mathrm{a})$, the optical band gap decreases significantly with increases in Fe concentrations. Figure 8(b) shows that the refractive index of codoped $\mathrm{ZnO}$ films is increased (at $\lambda=375 \mathrm{~nm}$ ) considerably for different doping (Fe) concentrations. This indicates that the light normally travels through the medium. Moreover, the extinction coefficient $(k)$ reveals the well smoothness of thin films surface.

Figure 9 shows the absorption coefficient $(\alpha)$ of $(\mathrm{K}, \mathrm{Fe})$ codoped $\mathrm{ZnO}$ thin films for different $\mathrm{Fe}$ doping concentrations. For $\mathrm{ZnO}: \mathrm{K}(1 \%), \alpha$ was $2.75 \times 10^{5} \mathrm{~cm}^{-1}$ [31]. In the UV region at $\lambda=375 \mathrm{~nm}$, absorption coefficient is $2.03 \times 10^{5} \mathrm{~cm}^{-1}, 2.48 \times 10^{5} \mathrm{~cm}^{-1}, 3.30 \times 10^{5} \mathrm{~cm}^{-1}$, and $3.95 \times 10^{5} \mathrm{~cm}^{-1}$ for $1,2,3$, and $4 \%$ of Fe, respectively. In the present investigation, in the UV region, the absorption of light depends on the thickness of the film. The higher absorption of $\mathrm{ZnO}$ thin films is suitable for antireflecting coating (ARC) and optoelectronic applications [44].

3.6. Photoluminescence Study. Figure 10 shows the photoluminescence spectrum of $(\mathrm{K}, \mathrm{Fe})$ codoped $\mathrm{ZnO}$ films at room temperature. Generally, UV emissions exist in the range between $360 \mathrm{~nm}$ and $380 \mathrm{~nm}$ [45]. The UV emission was observed at $389 \mathrm{~nm}$ for $\mathrm{ZnO}: \mathrm{K}(1 \%)$ [31]. In the present PL spectrum, UV emission appears around $345 \mathrm{~nm}(3.59 \mathrm{eV})$ due to the free exciton [46]. However, in the photoluminescence spectrum, the intensity of UV emission significantly varies for 1,2 , and $3 \%$ of $\mathrm{Fe}$ ion concentrations but the UV intensity is reduced for $4 \% \mathrm{Fe}$ ion concentration. This may be due to the low concentration of $\mathrm{Zn}$ and $\mathrm{O}$ and it can be seen in EDAX spectrum. This is the evidence for the variation of UV intensity in the photoluminescence. The weak blue emission is presented with low intensity at $437 \mathrm{~nm}$ due to the low interstitial of $\mathrm{Zn}$ [47]. The red emission is obtained in the range between $661 \mathrm{~nm}$ and $663 \mathrm{~nm}$ due to the surplus of oxygen or interstitials of oxygen [48]. The peak position of the photoluminescence depends on the contribution between the free exciton and transition between free electrons to acceptor bound holes [49]. And also the position and intensity of UV and red emissions in PL are enhanced by incorporation of $\mathrm{Fe}$ ion in $\mathrm{ZnO}$ lattice site. In this study photoluminescence spectrum clearly reveals that the codoped $\mathrm{ZnO}$ thin films are defect free.

\section{Conclusion}

In the current work, the optical properties of $(\mathrm{K}, \mathrm{Fe})$ codoped $\mathrm{ZnO}$ thin films synthesized on glass substrate by chemical bath deposition technique have been investigated. The X-ray diffraction analysis confirms the hexagonal crystal structure of $\mathrm{ZnO}$ thin films. The grains with hexagonal morphology were observed for different Fe ion concentrations. The average thin film surface roughness decreases with increase of $\mathrm{Fe}$ ion concentration. The optical transmittance decreases due to the film thickness. The optical band gap of codoped $\mathrm{ZnO}$ thin films decreases due to different doping concentration. The different optical properties such as refractive index and absorption coefficient revealed that the optical behavior of thin films and the low extinction coefficient value indicate the better quality of the film. The absorption coefficient shows an increase with doping concentration. The photoluminescence spectrum revealed that the codoped $\mathrm{ZnO}$ thin films are mostly defect free. The present study shows that codoped (K, 
$\mathrm{Fe}) \mathrm{ZnO}$ thin films can be suitable candidates for antireflecting coating (ARC) and optoelectronic devices.

\section{Conflict of Interests}

The authors declare that there is no conflict of interests regarding the publication of this paper.

\section{References}

[1] S. M. Hatch, J. Briscoe, A. Sapelkin et al., "Influence of anneal atmosphere on $\mathrm{ZnO}$-nanorod photoluminescent and morphological properties with self-powered photodetector performance," Journal of Applied Physics, vol. 113, no. 20, Article ID 204501, 2013.

[2] Y. Lu, X. Zhang, J. Huang et al., "Investigation on antireflection coatings for Al: $\mathrm{ZnO}$ in silicon thin-film solar cells," Optik, vol. 124, no. 18, pp. 3392-3395, 2013.

[3] M. Bär, J.-P. Theisen, R. G. Wilks et al., "Lateral inhomogeneity of the $\mathrm{Mg} /(\mathrm{Zn}+\mathrm{Mg})$ composition at the $(\mathrm{Zn}, \mathrm{Mg}) \mathrm{O} / \mathrm{CuIn}(\mathrm{S}, \mathrm{Se}) 2$ thin-film solar cell interface revealed by photoemission electron microscopy," Journal of Applied Physics, vol. 113, no. 19, Article ID 193709, 2013.

[4] R. Juday, E. M. Silva, J. Y. Huang, P. G. Caldas, R. Prioli, and F. A. Ponce, "Strain-related optical properties of $\mathrm{ZnO}$ crystals due to nanoindentation on various surface orientations," Journal of Applied Physics, vol. 113, no. 18, Article ID 183511, 2013.

[5] S. M. Abbas, S. T. Hussain, S. Ali, N. Ahmad, N. Ali, and S. Abbas, "Structure and electrochemical performance of $\mathrm{ZnO} / \mathrm{CNT}$ composite as anode material for lithium-ion batteries," Journal of Materials Science, vol. 48, no. 16, pp. 54295436, 2013.

[6] Z. Zeng, C. S. Garoufalis, A. F. Terzis, and S. Baskoutas, "Linear and nonlinear optical properties of $\mathrm{ZnO} / \mathrm{ZnS}$ and $\mathrm{ZnS} / \mathrm{ZnO}$ core shell quantum dots: effects of shell thickness, impurity, and dielectric environment," Journal of Applied Physics, vol. 114, no. 2, Article ID 023510, 2013.

[7] D. Chu, T. Hamada, K. Kato, and Y. Masuda, "Growth and electrical properties of $\mathrm{ZnO}$ films prepared by chemical bath deposition method," Physica Status Solidi A, vol. 206, no. 4, pp. 718-723, 2009.

[8] D. N. Montenegro, V. Hortelano, O. Martínez et al., "Influence of metal organic chemical vapour deposition growth conditions on vibrational and luminescent properties of $\mathrm{ZnO}$ nanorods," Journal of Applied Physics, vol. 113, no. 14, Article ID 143513, 2013.

[9] W. Mtangi, M. Schmidt, F. D. Auret et al., "A study of the $\mathrm{T}_{2}$ defect and the emission properties of the E3 deep level in annealed melt grown $\mathrm{ZnO}$ single crystals," Journal of Applied Physics, vol. 113, no. 12, Article ID 124502, 2013.

[10] J. E. Stehr, X. J. Wang, S. Filippov et al., "Defects in N, O and $\mathrm{N}$, Zn implanted ZnO bulk crystals," Journal of Applied Physics, vol. 113, no. 10, Article ID 103509, 2013.

[11] G. Chen, J. J. Peng, C. Song, F. Zeng, and F. Pan, "Interplay between chemical state, electric properties, and ferromagnetism in Fe-doped ZnO films," Journal of Applied Physics, vol. 113, no. 10, Article ID 104503, 2013.

[12] J. Joo, B. Y. Chow, M. Prakash, E. S. Boyden, and J. M. Jacobson, "Face-selective electrostatic control of hydrothermal zinc oxide nanowire sythesis," Nature Materials, vol. 10, pp. 596-601, 2011.
[13] S. S. Shinde, A. P. Korade, C. H. Bhosale, and K. Y. Rajpure, "Influence of tin doping onto structural, morphological, optoelectronic and impedance properties of sprayed $\mathrm{ZnO}$ thin films," Journal of Alloys and Compounds, vol. 551, pp. 688-693, 2013.

[14] S.-K. Kim, S. A. Kim, C.-H. Lee, H.-J. Lee, S.-Y. Jeong, and C. R. Cho, "The structural and optical behaviors of K-doped $\mathrm{ZnO} / \mathrm{Al}_{2} \mathrm{O}_{3}(0001)$ films," Applied Physics Letters, vol. 85, no. 3, pp. 419-421, 2004.

[15] L. Xu, F. Gu, J. Su, Y. Chen, X. Li, and X. Wang, "The evolution behavior of structures and photoluminescence of K-doped $\mathrm{ZnO}$ thin films under different annealing temperatures," Journal of Alloys and Compounds, vol. 509, no. 6, pp. 2942-2947, 2011.

[16] J. Lü, K. Huang, J. Zhu, X. Chen, X. Song, and Z. Sun, "Preparation and characterization of $\mathrm{Na}$-doped $\mathrm{ZnO}$ thin films by sol-gel method," Physica B, vol. 405, no. 15, pp. 3167-3171, 2010.

[17] W. Liu, F. Xiu, K. Sun et al., "Na-doped p-type ZnO microwires," Journal of the American Chemical Society, vol. 132, no. 8, pp. 2498-2499, 2010.

[18] S. Kumar and R. Thangavel, "Structural and optical properties of $\mathrm{Na}$ doped $\mathrm{ZnO}$ nanocrystalline thin films synthesized using sol-gel spin coating technique," Journal of Sol-Gel Science and Technology, vol. 67, no. 1, pp. 50-55, 2013.

[19] M. Joseph, H. Tabata, and T. Kawai, "Ferroelectric behavior of Li-doped $\mathrm{ZnO}$ thin films on $\mathrm{Si}(100)$ by pulsed laser deposition," Applied Physics Letters, vol. 74, no. 17, pp. 2534-2536, 1999.

[20] S. Kalyanaraman, R. Vettumperumal, and R. Thangavel, "Study of multiple phonon behavior in Li-doped $\mathrm{ZnO}$ thin films fabricated using the sol-gel spin-coating technique," Journal of the Korean Physical Society, vol. 62, no. 5, pp. 804-808, 2013.

[21] T. Rattana, S. Suwanboon, P. Amornpitoksuk, A. Haidoux, and P. Limsuwan, "Improvement of optical properties of nanocrystalline $\mathrm{Fe}$-doped $\mathrm{ZnO}$ powders through precipitation method from citrate-modified zinc nitrate solution," Journal of Alloys and Compounds, vol. 480, no. 2, pp. 603-607, 2009.

[22] Y. Zhang, L. Wu, H. Li et al., "Influence of Fe doping on the optical property of $\mathrm{ZnO}$ films," Journal of Alloys and Compounds, vol. 473, no. 1-2, pp. 319-322, 2009.

[23] M. Benhaliliba, Y. S. Ocak, and A. Tab, "Characterization of coated fe-doped zinc oxide nanostructures," Journal of Nano\& Electronic Physics, vol. 5, no. 3, 2013.

[24] J. Wang, J. Wan, and K. Chen, "Facile synthesis of superparamagnetic Fe-doped $\mathrm{ZnO}$ nanoparticles in liquid polyols," Materials Letters, vol. 64, no. 21, pp. 2373-2375, 2010.

[25] A. Sawalha, M. Abu Abdeen, and A. Sedky, "Electrical conductivity study in pure and doped $\mathrm{ZnO}$ ceramic system," Physica B, vol. 404, no. 8-11, pp. 1316-1320, 2009.

[26] J. Xu, S. Shi, X. Zhang, and Y. Wang, "Structural and optical properties of $(\mathrm{Al}, \mathrm{K})$-co-doped $\mathrm{ZnO}$ thin films deposited by a sol-gel technique," Materials Science in Semiconductor Processing, vol. 16, no. 3, pp. 732-737, 2013.

[27] D. Zhang, J. Zhang, Z. Guo, and X. Miao, “Optical and electrical properties of zinc oxide thin films with low resistivity via Li-N dual-acceptor doping," Journal of Alloys and Compounds, vol. 509, no. 20, pp. 5962-5968, 2011.

[28] S. Aksoy, Y. Caglar, S. Ilican, and M. Caglar, "Sol-gel derived Li$\mathrm{Mg}$ co-doped $\mathrm{ZnO}$ films: preparation and characterization via XRD, XPS, FESEM," Journal of Alloys and Compounds, vol. 512, no. 1, pp. 171-178, 2012. 
[29] J. J. Beltrán, J. A. Osorio, C. A. Barrero, C. B. Hanna, and A. Punnoose, "Magnetic properties of Fe doped, Co doped, and $\mathrm{Fe}+\mathrm{Co}$ co-doped ZnO," Journal of Applied Physics, vol. 113, no. 17, Article ID 17C308, 2013.

[30] S. Ghosh, M. Mandal, and K. Mandal, "Effects of Fe doping and $\mathrm{Fe}-\mathrm{N}$-codoping on magnetic properties of $\mathrm{SnO}_{2}$ prepared by chemical co-precipitation," Journal of Magnetism and Magnetic Materials, vol. 323, no. 8, pp. 1083-1087, 2011.

[31] G. Shanmuganathan, I. B. S. Banu, S. Krishnan, and B. Ranganathan, "Influence of K-doping on the optical properties of $\mathrm{ZnO}$ thin films grown by chemical bath deposition method," Journal of Alloys and Compounds, vol. 562, pp. 187-193, 2013.

[32] B. Zhang, S. Zhou, H. Wang, and Z. Du, "Raman scattering and photoluminescence of Fe-doped $\mathrm{ZnO}$ nanocantilever arrays," Chinese Science Bulletin, vol. 53, no. 11, pp. 1639-1643, 2008.

[33] C. S. Prajapati, A. Kushwaha, and P. P. Sahay, "Experimental investigation of spray-deposited $\mathrm{Fe}$-doped $\mathrm{ZnO}$ nanoparticle thin films: structural, microstructural and optical properties," JTTEES, vol. 22, p. 1232, 2013.

[34] L. $\mathrm{Xu}$ and $\mathrm{X}$. Li, "Influence of Fe-doping on the structural and optical properties of $\mathrm{ZnO}$ thin films prepared by sol-gel method," Journal of Crystal Growth, vol. 312, no. 6, pp. 851-855, 2010.

[35] L. C. Yang, R. X. Wang, S. J. Xu et al., "Effects of annealing temperature on the characteristics of Ga-doped $\mathrm{ZnO}$ film metal-semiconductor-metal ultraviolet photodetectors," Journal of Applied Physics, vol. 113, no. 8, Article ID 084501, 2013.

[36] S. Saha and V. Gupta, "Al and Fe co-doped transparent conducting $\mathrm{ZnO}$ thin film for mediator-less biosensing application," Journal of Applied Physics, vol. 1, Article ID 042112, 3 pages, 2013.

[37] K. A. Eswar, A. Azlinda, H. F. Husairi, M. Rusop, and S. Abdullah, "Post annealing effect on thin film composed $\mathrm{ZnO}$ nano-particles on porous silicon," Nano Bulletin, vol. 2, p. 130212-3, 2013

[38] L. Xu and X. Li, "Influence of Fe-doping on the structural and optical properties of $\mathrm{ZnO}$ thin films prepared by sol-gel method," Journal of Crystal Growth, vol. 312, no. 6, pp. 851-855, 2010.

[39] S. M. Salaken, E. Farzana, and J. Podder, "Effect of Fe-doping on the structural and optical properties of $\mathrm{ZnO}$ thin films prepared by spray pyrolysis," Chinese Institute of Electronics, vol. 34, Article ID 073003, 6 pages, 2013.

[40] C. S. Prajapati, A. Kushwaha, and P. P. Sahay, "Experimental investigation of spray-deposited fe-doped $\mathrm{ZnO}$ nanoparticle thin films: structural, microstructural, and optical properties," Journal of Thermal Spray Technology, vol. 22, no. 7, pp. 12301241, 2013.

[41] T. Wang, Y. Liu, Q. Fang et al., "Morphology and optical properties of Co doped $\mathrm{ZnO}$ textured thin films," Journal of Alloys and Compounds, vol. 509, no. 37, pp. 9116-9122, 2011.

[42] M. Öztas and M. Bedir, "Thickness dependence of structural, electrical and optical properties of sprayed $\mathrm{ZnO}: \mathrm{Cu}$ films," Thin Solid Films, vol. 516, no. 8, pp. 1703-1709, 2008.

[43] A. A. Ziabari and F. E. Ghodsi, "Optoelectronic studies of sol-gel derived nanostructured $\mathrm{CdO}-\mathrm{ZnO}$ composite films," Journal of Alloys and Compounds, vol. 509, no. 35, pp. 8748-8755, 2011.

[44] Q. G. Du, G. Alagappan, H. Dai et al., "UV-blocking ZnO nanostructure anti-reflective coatings," Optics Communications, vol. 285, no. 13-14, pp. 3238-3241, 2012.

[45] O. Lupana, T. Pauporte, L. Chowc et al., "Effects of annealing on properties of $\mathrm{ZnO}$ thin films prepared by electrochemical deposition in chloride medium," Applied Surface Science, vol. 256, pp. 1895-1907, 2010.

[46] Z. R. Khan, M. S. Khan, M. Zulfequar, and M. S. Khan, “Optical and structural properties of $\mathrm{ZnO}$ thin films fabricated by SolGel method," Materials Sciences and Applications, vol. 2, no. 5, pp. 340-345, 2011.

[47] B. Y. Erdoan, "The alloying effects on the structural and optical properties of nanocrystalline copper zinc oxide thin films fabricated by spin coating and annealing method," Journal of Alloys and Compounds, vol. 502, no. 2, pp. 445-450, 2010.

[48] A. S. Kuznetsov, Y.-G. Lu, S. Turner et al., "Preparation, structural and optical characterization of nanocrystalline $\mathrm{ZnO}$ doped with luminescent Ag-nanoclusters," Optical Materials Express, vol. 2, no. 6, pp. 723-734, 2012.

[49] M. Gao, J. Yang, L. Yang et al., "Enhancement of optical properties and donor-related emissions in Y-doped ZnO," Superlattices and Microstructures, vol. 52, no. 1, pp. 84-91, 2012. 

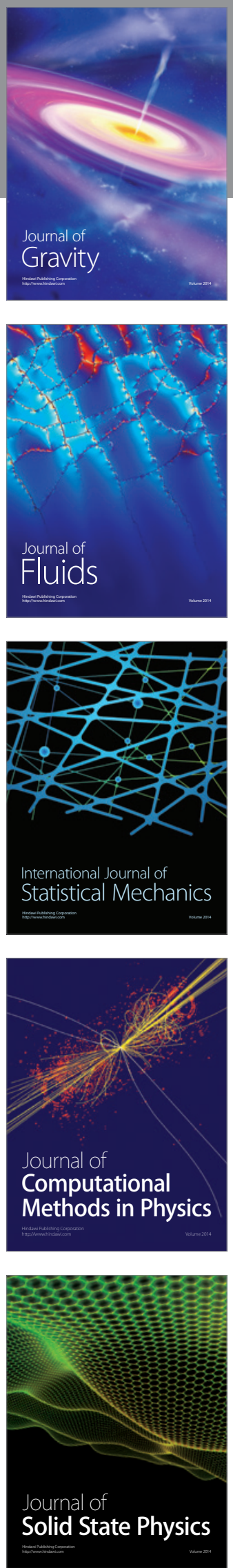

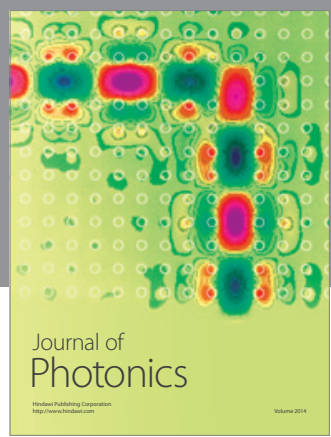

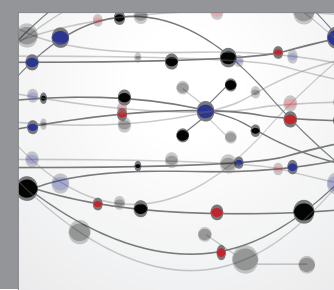

The Scientific World Journal

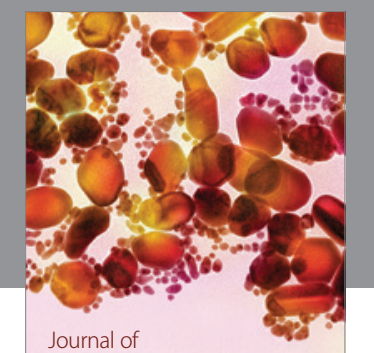

Soft Matter
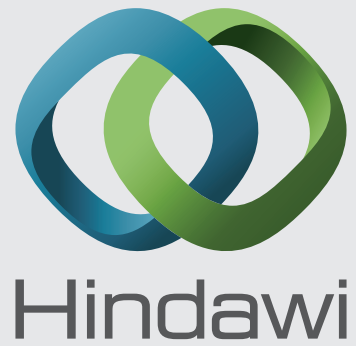

Submit your manuscripts at

http://www.hindawi.com
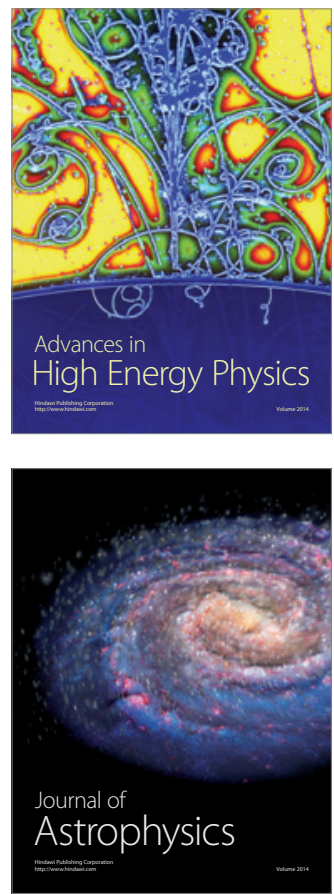
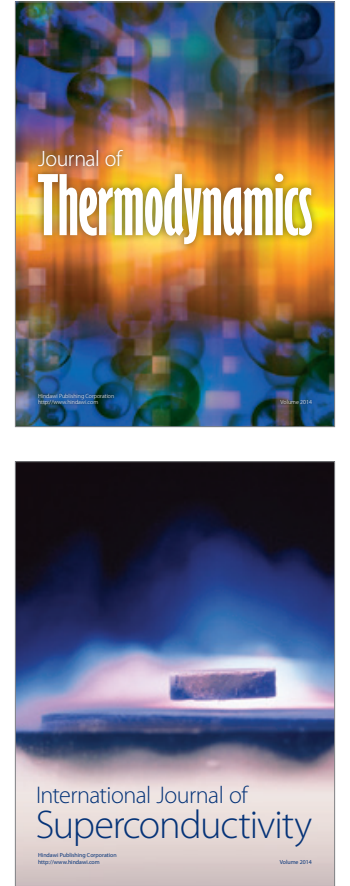
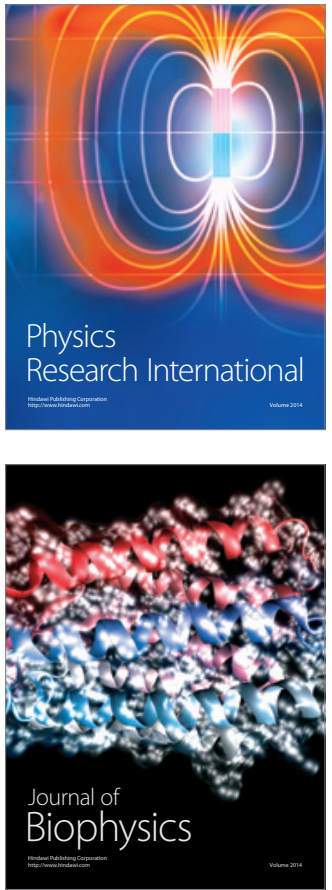
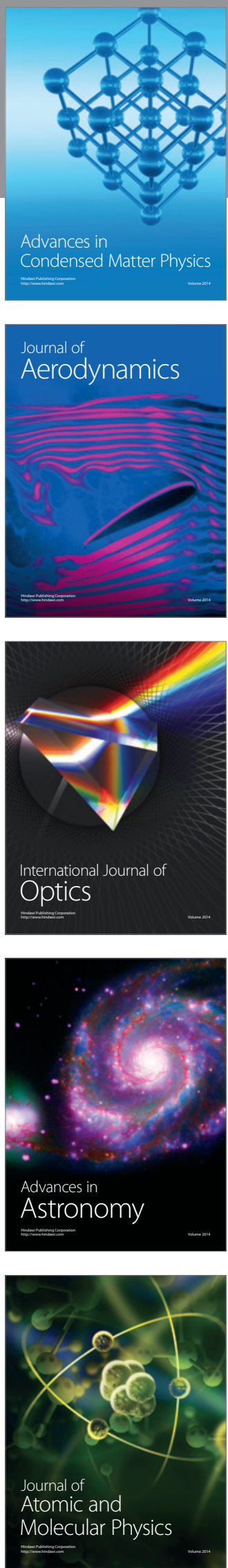